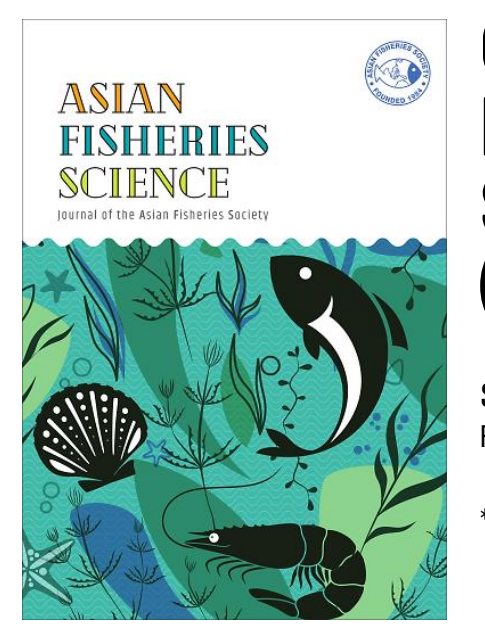

\title{
Composition, Abundance and Distribution of Fish Eggs in Sarawak Exclusive Economic Zone (EEZ) of the South China Sea
}

\author{
SITI AKMAR KHADIJAH AB RAHIM, AINIL SYAMIN ALIAS* \\ Faculty of Resource Science and Technology, Universiti Malaysia Sarawak, 94300 Kota Samarahan, Sarawak, Malaysia \\ *E-mail: ainilsyamin149@gmail.com | Received: 22/03/2020; Accepted: 30/08/2020
}

() Asian Fisheries Society

ISSN: 0116-6514

E-ISSN: 2073-3720

https://doi.org/10.33997/j.afs.2020.33.3.004

\begin{abstract}
Fish eggs are categorised as ichthyoplankton and most pelagic eggs are distributed in or just below the photic zone. The study of the fish egg is crucial in understanding the dynamics of fish populations, but information on fish eggs in the Sarawak exclusive economic zone (EEZ) is still lacking. This study reports the fish eggs composition, abundance and distribution at 38 stations within three zones in the Sarawak EEZ. The eggs were sampled from 19 August to 6 October 2015 using a bongo net (330 $\mu \mathrm{m}$ and $500 \mu \mathrm{m}$ mesh-size), obliquely towed at a speed of 2 to $3 \mathrm{knots}$ for $20 \mathrm{~min}$. Selected physicochemical water parameters were also collected according to the depth profile. Preserved fish eggs were identified to the family level. Density and diversity of fish eggs were calculated. The influence of environmental factors on fish egg abundance according to zone was tested with canonical correspondence analyses (CCA). A total of 3,935 fish eggs belonging to 6 orders and 12 families were successfully collected whereby Carangidae, Clupeidae and Scombridae showed high abundance (>10\%). The highest mean density was recorded at the inner neritic zone while the Jaccard's dissimilarity index ranged from $0 \%$ to $25 \%$ among the three zones. Based on CCA, the abundance of Labridae, Malacostidae, Muraenidae, Scombridae and Sphyraenidae were influenced by environmental factors. The findings of this paper are useful for future fishery management in Sarawak EEZ.
\end{abstract}

Keywords: density, environmental factors, ichthyoplankton, bottom depth, depth profile

\section{Introduction}

Fish eggs are part of ichthyoplankton and they drift in the ocean along with the water currents. Most eggs are distributed in or just below the photic zone, especially within the upper 150 to $200 \mathrm{~m}$ of bottom depth (Ahlstrom and Moser, 1976). About $75 \%$ of teleost species produce pelagic (buoyant) eggs and are fertilised and float individually (although a few species have floating egg masses), usually near the water surface (Miller and Kendall, 2012). Most fish eggs are either spherical or ellipsoidal, and their sizes depend on species (Fish Database of Taiwan, 2014).

The study of fish eggs is crucial in understanding the dynamics of fish populations. In fishery management, knowledge on the distribution and abundance of ichthyoplankton obtained through plankton surveys contributed to the understanding of the spatial distribution of fisheries resources and the processes affecting the fluctuations in recruitment (Kelso and Rutherford, 1996). Furthermore, information on the distribution and abundance of the ichthyoplankton is important to fishery biologist and fishers regarding spawning locales and seasons, as well as improved understanding of reproductive dynamics (Sanches et al., 1999).

The Malaysian EEZ that includes the South China Sea supports high sea fisheries. This study is important to help Malaysia fisheries in identifying the spawning areas that should be protected and managed as a nursing area to ensure the survival of juvenile commercially important fish species. Thus, the identified areas could be gazetted as closed fishing areas or areas that are zoned for specific fishing gear to conserve the marine resources. However, previous studies carried out in Malaysia by Blaber et al. (1997) 
studied ichthyoplankton focused on selected estuaries in Sarawak and Sabah. Recently, ichthyoplankton studies were done to compare the larval fish density between seagrass beds and outside of seagrass beds of the Southwestern Johor (Ara et al., 2011a). Muhamad and Rahim (2014) studied fish larvae in selected coastal waters (Teluk Pandan beach, Rambungan beach, Puteri beach, Sampadi Island and Satang Besar Island) of Sarawak. Muhamad (2017) carried out a recent study focused on ichthyoplankton assemblages and its distribution along the selected Sarawak coastal waters.

The previous studies focused on fish larvae without detail information on marine fish eggs, especially their assemblages. Thus, the present study aimed to assess the composition, abundance and distribution of fish eggs at three depth zones (inner, middle and outer neritic zone) in the Sarawak EEZ of the South China Sea. Furthermore, the influence of physicochemical water parameters on the density of fish eggs family was described. Being the first baseline study for Sarawak EEZ waters, the findings will be useful for future fisheries management of commercially important marine fish in Malaysia.

\section{Materials and Methods}

\section{Sampling area}

This study was performed from 19 August to 6 October 2015 at 38 stations within the Sarawak EEZ, South China Sea (Fig. 1) onboard MV SEAFDEC 2 research vessel. Details of each station are shown in Table 1. Based on distance, sampling areas were categorised as inshore area (less than 50 nautical miles) and offshore area (more than 50 nautical miles) while depending on the bottom depth of the station, sampling areas were categorised into three depth zones namely: Inner (15 stations; 20-50 m), Middle (12 stations; $51-100 \mathrm{~m}$ ) and Outer (11 stations; 101-200 m) neritic zones. This study did not cover areas from depth $0-20 \mathrm{~m}$ due to the large size of ship which cannot anchor in the depth of less than $20 \mathrm{~m}$.

\section{Sampling strategy}

Fish eggs were collected using a bongo net with mesh-size of $330 \mu \mathrm{m}$ and $500 \mu \mathrm{m}$. At each station, the bongo net was towed obliquely at a towing speed of 23 knots for about $20 \mathrm{~min}$ (10 min downward and $10 \mathrm{~min}$ upward). The $0.5 \mathrm{~m}$ diameter opening of each net was attached with a flow meter to measure the volume of water filtered during sampling (Posgay and Marak, 1980; Rester et al., 1998). The samples obtained were immediately preserved in $10 \%$ buffered formalin diluted with seawater and brought back to the laboratory for further analysis. Selected in-situ physicochemical water parameters were recorded only at 15 stations based on neritic zones (Inner: Station 2, 6 and 48; Middle: Station 27, 74, 76, 77 and 108; Outer: Station 116, 117, 118, 130, 133, 136 and 139) according to depth profile from the surface to the bottom (Table 1). Water samples were collected using a $5 \mathrm{~L}$ Van Dorn water sampler (high-density polyethylene), for the measurement of temperature and dissolved oxygen (DO) (Extech instrument SPL 150, USA), salinity (Atago PAL-06s salinometer, USA), turbidity (Eutech instrument TN 100, USA) and $\mathrm{pH}$ (Extech instrument SPL 100, USA).

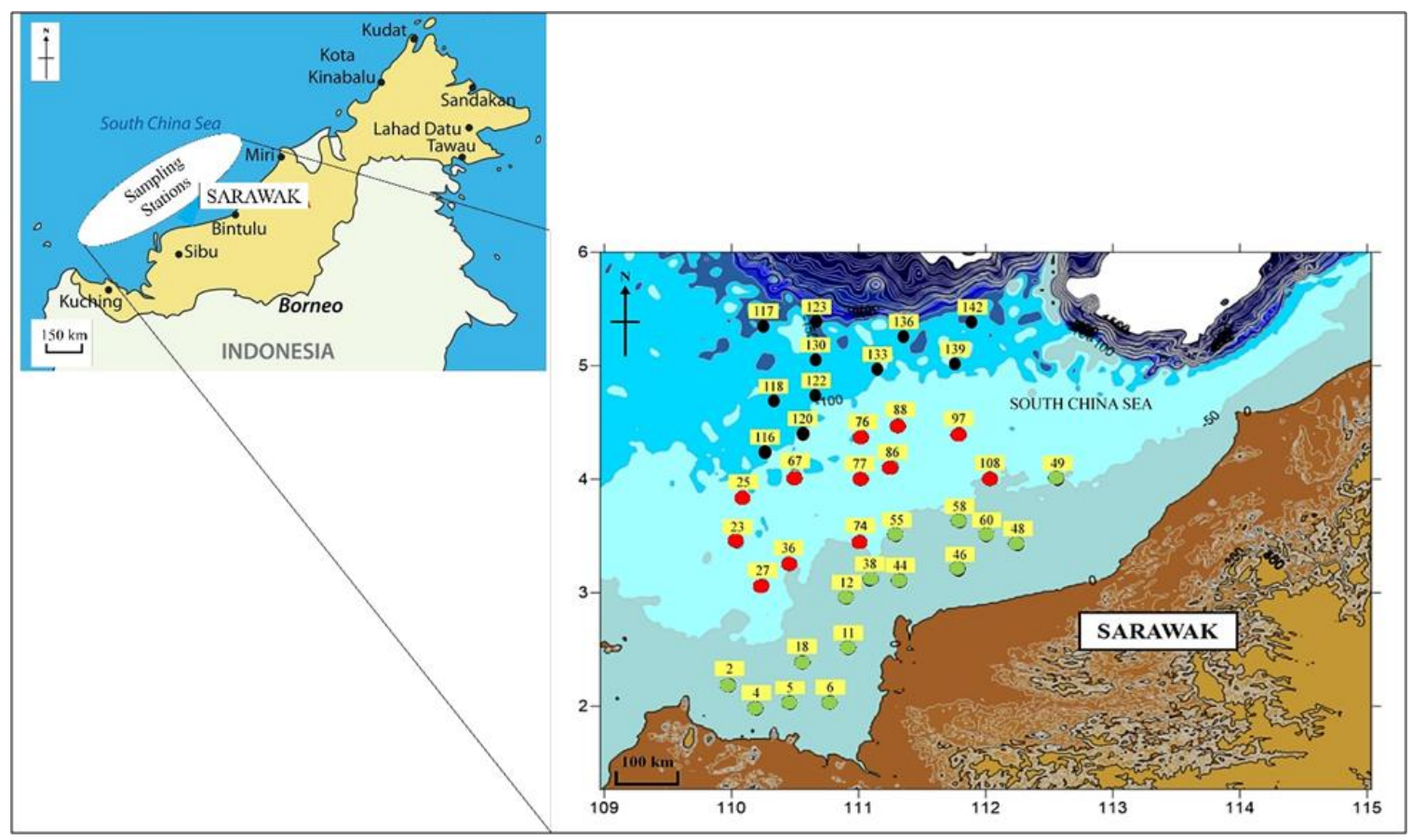

Fig. 1. Location of 38 stations within the Sarawak exclusive economic zone, South China Sea. The samples of the fish eggs were collected from $\mathbf{O}=$ Inner; $\mathbf{O}=$ Middle; $\mathbf{O}=$ Outer zones. 


\begin{tabular}{|c|c|c|c|c|c|c|c|c|}
\hline $\begin{array}{l}\text { Area } \\
(\mathrm{nm})\end{array}$ & $\begin{array}{l}\text { Neritic } \\
\text { zone }\end{array}$ & $\begin{array}{l}\text { Date } \\
\text { (2015) }\end{array}$ & Coordinates & $\begin{array}{l}\text { Station } \\
\text { no. }\end{array}$ & $\begin{array}{l}\text { Depth } \\
\text { (m) }\end{array}$ & $\begin{array}{l}\text { Max. } \\
\text { towing } \\
\text { depth } \\
(\mathrm{m})\end{array}$ & $\begin{array}{l}\text { Depth of water } \\
\text { sample collection } \\
(\mathrm{m})\end{array}$ & $\begin{array}{l}\text { Type of } \\
\text { bottom }\end{array}$ \\
\hline \multirow[t]{15}{*}{ Inshore } & Inner & $02 / 09$ & N $03^{\circ} 15^{\prime} 49^{\prime \prime}$ E $112^{\circ} 12^{\prime} 02^{\prime \prime}$ & 46 & 27 & 20 & & M \\
\hline & $(20-50 \mathrm{~m})$ & $10 / 09$ & N $03^{\circ} 08^{\prime} 37^{\prime \prime}$ E $111^{\circ} 38^{\prime} 37^{\prime \prime}$ & 44 & 30 & 20 & & M, Sh \\
\hline & & 20/09 & N $02^{\circ} 38^{\prime} 45^{\prime \prime}$ E $110^{\circ} 52^{\prime} 49^{\prime \prime}$ & 11 & 30 & 25 & & $N / R$ \\
\hline & & $06 / 10$ & N $02^{\circ} 06^{\prime} 36^{\prime \prime}$ E $110^{\circ} 04^{\prime} 16^{\prime \prime}$ & 4 & 31 & 22 & & M \\
\hline & & $23 / 08$ & N $03^{\circ} 37^{\prime} 28^{\prime \prime} E 112^{\circ} 50^{\prime} 93^{\prime \prime}$ & 48 & 34 & 30 & $3,10,15,20,30$ & $S, M$ \\
\hline & & 20/09 & N $02^{\circ} 55^{\prime} 04^{\prime \prime}$ E $110^{\circ} 50^{\prime} 69^{\prime \prime}$ & 12 & 36 & 28 & & $M, S$ \\
\hline & & $02 / 10$ & N $02^{\circ} 17^{\prime} 95^{\prime \prime}$ E $109^{\circ} 52^{\prime} 09^{\prime \prime}$ & 2 & 37 & 29 & $3,10,15,20,30$ & $M, S$ \\
\hline & & $20 / 09$ & N $02^{\circ} 32^{\prime} 78^{\prime \prime}$ E $110^{\circ} 27^{\prime} 78^{\prime \prime}$ & 18 & 38 & 33 & & $N / R$ \\
\hline & & $01 / 09$ & N $03^{\circ} 37^{\prime} 62^{\prime \prime}$ E $111^{\circ} 47^{\prime} 90^{\prime \prime}$ & 55 & 41 & 35 & & $M, S$ \\
\hline & & $22 / 08$ & 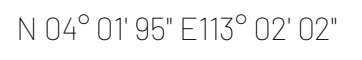 & 49 & 45 & 35 & & S \\
\hline & & $26 / 08$ & N $03^{\circ} 37^{\prime} 62^{\prime \prime}$ E $112^{\circ} 32^{\prime} 45^{\prime \prime}$ & 60 & 45 & 35 & & $S, M$ \\
\hline & & $16 / 09$ & N $03^{\circ} 13^{\prime} 15^{\prime \prime}$ E $111^{\circ} 12^{\prime} 77^{\prime \prime}$ & 38 & 47 & 30 & & M \\
\hline & & $27 / 08$ & N $03^{\circ} 57^{\prime} 41^{\prime \prime}$ E $112^{\circ} 11^{\prime} 71^{\prime \prime}$ & 58 & 50 & 35 & & $N / R$ \\
\hline & & $20 / 09$ & N $02^{\circ} 14^{\prime} 45^{\prime \prime}$ E $110^{\circ} 23^{\prime} 32^{\prime \prime}$ & 5 & 50 & 40 & & $M, S$ \\
\hline & & 20/09 & N $02^{\circ} 12^{\prime} 44^{\prime \prime}$ E $110^{\circ} 40^{\prime} 85^{\prime \prime}$ & 6 & 50 & 40 & $3,10,15,20,30$ & $N / R$ \\
\hline \multirow[t]{23}{*}{ Offshore } & Middle & $22 / 08$ & 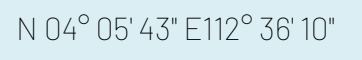 & 108 & 59 & 35 & $3,10,15,20,30,50$ & M \\
\hline & $(51-100 \mathrm{~m})$ & 09/09 & N $03^{\circ} 37^{\prime} 11^{\prime \prime}$ E $111^{\circ} 12^{\prime} 34^{\prime \prime}$ & 74 & 63 & 50 & $3,10,15,20,30,50$ & $M, C$ \\
\hline & & $08 / 09$ & N $04^{\circ} 09^{\prime} 73^{\prime \prime}$ E $111^{\circ} 16^{\prime} 67^{\prime \prime}$ & 77 & 69 & 65 & $3,10,15,20,30,50$ & $N / R$ \\
\hline & & $03 / 10$ & N $03^{\circ} 20^{\prime} 25^{\prime \prime}$ E $110^{\circ} 20^{\prime} 50^{\prime \prime}$ & 36 & 73 & 68 & & $M, S$ \\
\hline & & $28 / 08$ & N $04^{\circ} 17^{\prime} 28^{\prime \prime}$ E $111^{\circ} 42^{\prime} 78^{\prime \prime}$ & 86 & 75 & 60 & & $M, S, S h$ \\
\hline & & 05/10 & N $03^{\circ} 31^{\prime} 80^{\prime \prime}$ E $109^{\circ} 56^{\prime} 14^{\prime \prime}$ & 23 & 76 & 66 & & $N / R$ \\
\hline & & $03 / 10$ & N $03^{\circ} 10^{\prime} 89^{\prime \prime}$ E $110^{\circ} 10^{\prime} 26^{\prime \prime}$ & 27 & 77 & 70 & $3,10,15,20,30,50$ & $N / R$ \\
\hline & & $21 / 08$ & N $04^{\circ} 37^{\prime} 54^{\prime \prime}$ E112 $07^{\circ} 87^{\prime \prime}$ & 97 & 84 & 58 & & M \\
\hline & & $08 / 09$ & N $04^{\circ} 12^{\prime} 48^{\prime \prime}$ E $110^{\circ} 42^{\prime} 80^{\prime \prime}$ & 67 & 89 & 80 & & $N / R$ \\
\hline & & $07 / 09$ & N $04^{\circ} 12^{\prime} 48^{\prime \prime}$ E $111^{\circ} 12^{\prime} 50^{\prime \prime}$ & 76 & 92 & 80 & $3,10,20,40,60,80$ & M \\
\hline & & 29/08 & N $04^{\circ} 47^{\prime} 89^{\prime \prime}$ E $111^{\circ} 40^{\prime} 98^{\prime \prime}$ & 88 & 95 & 80 & & $M, S$ \\
\hline & & $05 / 10$ & N $03^{\circ} 55^{\prime} 16^{\prime \prime}$ E $110^{\circ} 00^{\prime} 15^{\prime \prime}$ & 25 & 97 & 85 & & $N / R$ \\
\hline & Outer & $17 / 09$ & N $04^{\circ} 27^{\prime} 69^{\prime \prime}$ E $110^{\circ} 27^{\prime} 62^{\prime \prime}$ & 120 & 104 & 90 & & M \\
\hline & $(101-200 \mathrm{~m})$ & $19 / 09$ & N $04^{\circ} 19^{\prime} 37^{\prime \prime}$ E $110^{\circ} 08^{\prime} 97^{\prime \prime}$ & 116 & 104 & 90 & $3,20,40,60,80$ & $M, S$ \\
\hline & & $30 / 08$ & N $04^{\circ} 57^{\prime} 41^{\prime \prime}$ E $111^{\circ} 22^{\prime} 68^{\prime \prime}$ & 133 & 105 & 80 & $3,20,40,60,80,100$ & M \\
\hline & & 20/08 & N $05^{\circ} 07^{\prime} 51^{\prime \prime}$ E112 $02^{\prime} 70^{\prime \prime}$ & 139 & 113 & 80 & $3,20,40,60,80,100$ & C \\
\hline & & $19 / 09$ & N $04^{\circ} 47^{\prime} 44^{\prime \prime} \mathrm{E} 110^{\circ} 12^{\prime} 47^{\prime \prime}$ & 118 & 121 & 112 & $3,20,40,60,80,100$ & $N / R$ \\
\hline & & $19 / 09$ & N $04^{\circ} 52^{\prime} 39^{\prime \prime}$ E $110^{\circ} 32^{\prime} 18^{\prime \prime}$ & 122 & 121 & 110 & & $N / R$ \\
\hline & & $06 / 09$ & N $05^{\circ} 16^{\prime} 29^{\prime \prime}$ E $110^{\circ} 57^{\prime} 37^{\prime \prime}$ & 130 & 135 & 115 & $3,20,60,80,100,120$ & $M, S$ \\
\hline & & $30 / 08$ & N $05^{\circ} 27^{\prime} 54^{\prime \prime}$ E $111^{\circ} 47^{\prime} 83^{\prime \prime}$ & 136 & 150 & 103 & $3,20,50,100,150$ & $M, S$ \\
\hline & & $18 / 09$ & N $05^{\circ} 21^{\prime} 53^{\prime \prime}$ E $110^{\circ} 08^{\prime} 41^{\prime \prime}$ & 117 & 153 & 125 & $3,20,50,80,100,150$ & $N / R$ \\
\hline & & $18 / 09$ & N $05^{\circ} 23^{\prime} 27^{\prime \prime}$ E $110^{\circ} 34^{\prime} 04^{\prime \prime}$ & 123 & 157 & 85 & & M \\
\hline & & 19/08 & N $05^{\circ} 37^{\prime} 28^{\prime \prime}$ E $112^{\circ} 07^{\prime} 77^{\prime \prime}$ & 142 & 175 & 90 & & $M, S$ \\
\hline
\end{tabular}




\section{Sample processing and identification}

Ichthyoplankton samples obtained from the Sarawak EEZ were processed in the Aquatic Invertebrates Laboratory, Faculty of Resources Science and Technology, Universiti Malaysia Sarawak. The fish egg samples were sorted from other zooplankton and debris according to their morphological characters. With the aid of a stereo microscope (Motic, model SMZ-168, Hong Kong) equipped with a digital camera (Moticam 352, Hong Kong), fish eggs identification was performed to the family level based on the works of Jeyaseelan (1998), Ré and Meneses (2008), Okiyama (2014) and also Professor Dr Izumi Kinoshita, an ichthyologist from Kochi University, Japan. The total number of fish eggs found from three neritic zones was counted according to their family and samples that could not be identified were placed in the unidentified category.

\section{Data and statistical analysis}

The density of fish egg samples was standardised for each station and expressed as the number of fish eggs per $100 \mathrm{~m}^{3}$ of filtered water. Then, the mean and standard deviation of fish eggs density was calculated. The dissimilarity of fish egg assemblages according to three zones was calculated using Jaccard's dissimilarity index (Whittaker, 1960) as follows:

Jaccard's dissimilarity index, $a=1-\frac{a}{a+b+c}$

where,

a indicates number of families shared between two zones

$b$ indicates number of families unique to zone one $c$ indicates number of families unique to zone two

Meanwhile, the in-situ physicochemical water parameters (salinity, temperature, turbidity, $\mathrm{pH}$ and DO) of 15 stations were reported in range according to three neritic zones. Pearson correlation coefficient was used to analyse the relationship between mean values of physicochemical water parameters and water depth at three zones (SPSS version 23.0).

The relationship between the abundance of fish egg family, as well as the influence of environmental factors (zone, temperature, pH, turbidity, DO and salinity), was tested using canonical correspondence analyses (CCA) (Ter Braak, 1986, 1994). The significance of each variable was tested using PAST 3.14. The result was presented using canonical biplot to identify environmental gradients in the series of data on environmental factors, particularly those factors that are significant in determining the community composition. The level of significance was set at $95 \%(P<0.05)$ to reject the null hypothesis for all the analyses mentioned above.

\section{Results}

\section{Composition of fish eggs}

A total number of 3,935 fish eggs belonging to six orders and 12 families were collected from the Sarawak EEZ of the South China Sea. Based on the percentage composition, order Perciformes was the most dominant with $49.30 \%$ of the eggs, followed by Pleuronectiformes $(12.81 \%)$ and Clupeiformes $(12.20$ \%)(Fig. 2).

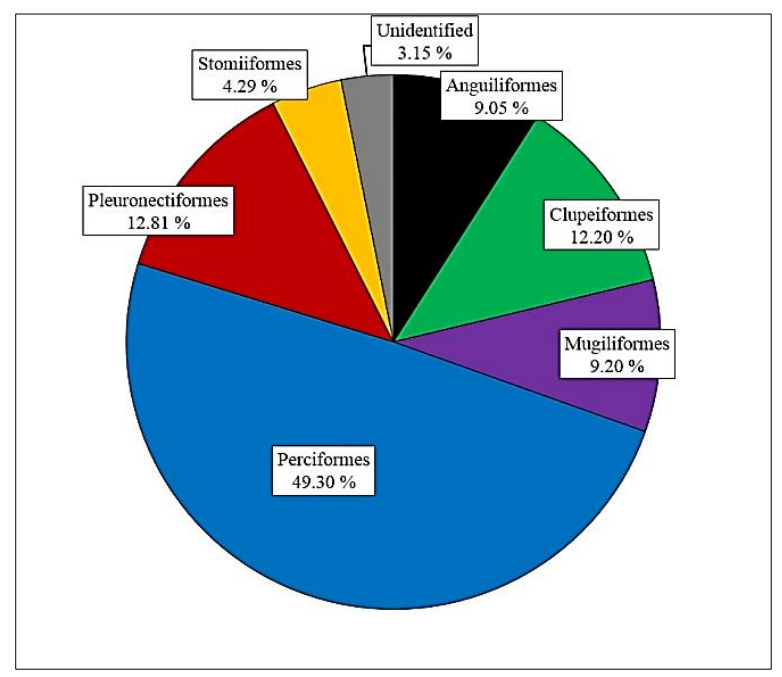

Fig. 2. Composition percentage of fish eggs according to order level found in the Sarawak EEZ of the South China Sea.

Based on family, Carangidae was the most dominant family throughout this study, contributing $14.89 \%$ from the total fish eggs and followed by Clupeidae $(12.20 \%)$ and Scombridae $(11.26 \%)$, while the least dominant family was Sphyraenidae (3.10\%). The other eight families contributed around $4.29 \%$ to $9.63 \%$. In this study, eggs from five commercial families were recorded, namely Clupeidae, Carangidae, Labridae, Scombridae and Sphyraenidae (Table 2).

Overall, the number of fish eggs collected at all three zones ranged from 1,214 to 1,355 eggs with the highest value recorded in the inner neritic zone and the lowest was in middle neritic zone (Fig. 3). However, among the three zones, the middle and outer neritic zones recorded an equal number of families ( 11 families), while the inner neritic zone had 10 families (Fig. 4)

\section{Density of fish eggs}

The mean density of fish eggs collected in the three neritic zones ranged from $20.57 \pm 7.85$ to $24.57 \pm 14.85$ FE. $100 \mathrm{~m}^{-3}$ and the highest value was recorded in the inner neritic zone while the lowest value was in the outer neritic zone (Fig. 5). Overall, eggs from the family Carangidae was the most dominant with 11.11 FE.100 $\mathrm{m}^{-3}$ followed by Clupeidae 


\begin{tabular}{llll}
\hline Order & Family & Number of individuals (N) & Composition (\%) \\
\hline Anguilliformes & Muraenidae & 356 & 9.05 \\
Clupeiformes & *Clupeidae & 480 & 12.20 \\
Mugiliformes & Mugilidae & 362 & 9.20 \\
\hline Perciformes & Callionymidae & 231 & 5.87 \\
& *Carangidae & 586 & 14.89 \\
& Kyphosidae & 4.55 \\
& *Labridae & 179 & 9.63 \\
& *Scombridae & 379 & 11.26 \\
*Sphyraenidae & 443 & 3.10 \\
Pleuronectiformes & Cynoglossidae & 122 & 7.55 \\
Stomiiformes & Soleidae & 297 & 5.26 \\
Unidentified sample & Malacostidae & 169 & 4.29 \\
\hline Total & & 124 & 3.15 \\
\hline *Fishfamily of commercia & & 3,935 & 100.00 \\
\hline
\end{tabular}

*Fish family of commercial value.

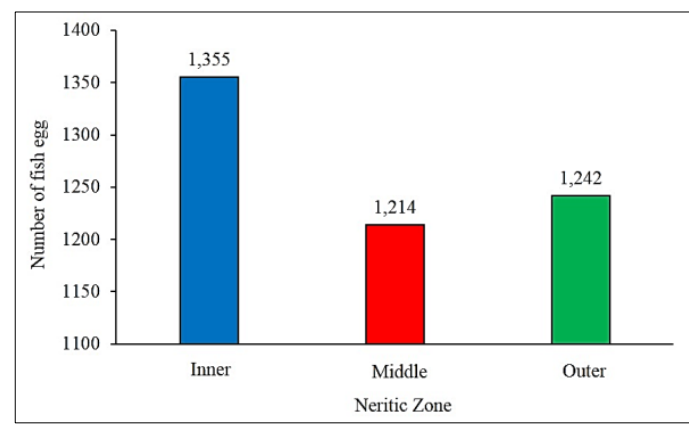

Fig. 3. Number of fish eggs collected in different neritic zones within the Sarawak EEZ of the South China Sea.

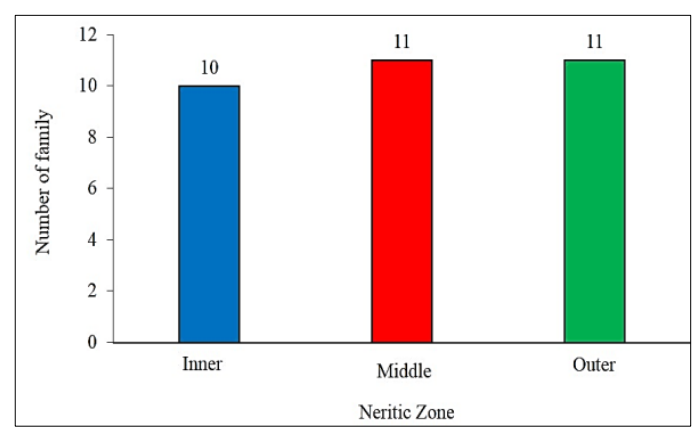

Fig. 4. Number of families identified from the fish eggs collected in the three neritic zones within the Sarawak EEZ of the South China Sea.

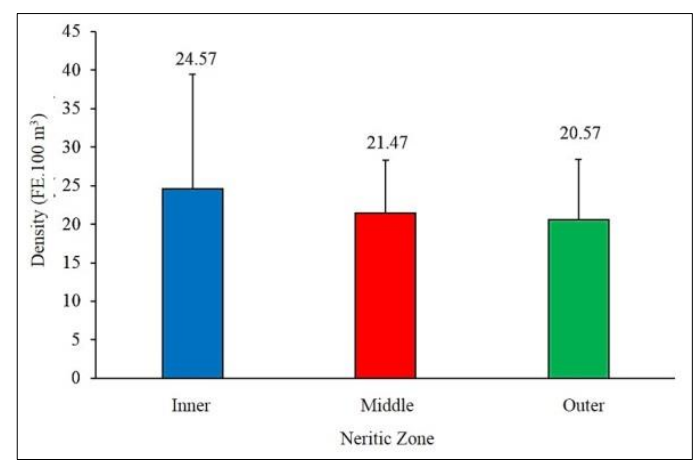

Fig. 5. Density of fish eggs collected in three neritic zones in the Sarawak EEZ of the South China Sea.
(8.55 FE.100 $\mathrm{m}^{-3}$ ) and Scombridae (7.82 FE.100 $\mathrm{m}^{-3}$ ) (Table 3). Based on zone, Carangidae, Clupeidae and Scombridae recorded the highest density in the inner neritic zone, while Scombridae, Mugilidae and Clupeidae showed the highest density in middle neritic zone. At outer neritic zone, the top three families that showed the highest density were Carangidae, Muraenidae and Clupeidae. However, two families, namely Kyphosidae and Malacostidae were absent in the inner neritic zone, while Sphyraenidae was absent in the middle and outer neritic zones (Table 3).

\section{Jaccard's dissimilarity index of fish egg assemblages}

The details of Jaccard's dissimilarity index are summarised in Table 4. Comparison of the index showed similar value with inner versus outer neritic zones which are $25 \%$ dissimilarity in the family assemblages. Meanwhile, the middle versus outer neritic zones recorded $0 \%$ indicating no differences in the assemblage

\section{Physicochemical water parameters of three neritic zones}

The physicochemical parameters of the water column at three neritic zones in the Sarawak EEZ of the South China Sea are summarised in Table 5. At the inner neritic zone, the temperature range was between $27.70{ }^{\circ} \mathrm{C}$ and $30.13^{\circ} \mathrm{C}$. Salinity values obtained in this study were between $33.60 \mathrm{PSU}$ to $34.80 \mathrm{PSU}$ and the surface water showed lower salinity than the bottom water layer. The DO ranged from $4.83 \mathrm{mg} \cdot \mathrm{L}^{-1}$ to 6.17 $\mathrm{mg} . \mathrm{L}^{-1}$ and turbidity obtained was very low (0.01 NTU to 0.30 NTU). Whereas, the $\mathrm{pH}$ value ranged from 7.50 to 7.79 .

At middle neritic zone, the temperature range was lower than the inner neritic zone $\left(21.68^{\circ} \mathrm{C}\right.$ to $\left.28.90^{\circ} \mathrm{C}\right)$. The salinity range at this zone was higher (34.00 PSU to $35.13 \mathrm{PSU}$ ) than the inner neritic zone. For DO, the 
Table 3. Density of fish eggs per $100 \mathrm{~m}^{3}$ according to families that were collected at three neritic zones in the Sarawak EEZ of the South China Sea.

\begin{tabular}{|c|c|c|c|c|}
\hline \multirow{3}{*}{ Family } & \multicolumn{3}{|c|}{ Density (FE. $\left.100 \mathrm{~m}^{-3}\right)$} & \multirow{3}{*}{ Total } \\
\hline & \multicolumn{3}{|c|}{ Neritic zone } & \\
\hline & Inner & Middle & Outer & \\
\hline Callionymidae & 1.37 & 1.65 & 0.79 & 3.81 \\
\hline Carangidae & 5.74 & 2.15 & 3.22 & 11.11 \\
\hline Clupeidae & 3.74 & 2.31 & 2.50 & 8.55 \\
\hline Cynoglossidae & 1.13 & 1.99 & 1.67 & 4.79 \\
\hline Kyphosidae & 0.00 & 1.10 & 1.79 & 2.89 \\
\hline Labridae & 2.31 & 2.17 & 2.17 & 6.65 \\
\hline Malacostidae & 0.00 & 1.38 & 1.53 & 2.91 \\
\hline Mugilidae & 1.96 & 2.54 & 1.63 & 6.13 \\
\hline Muraenidae & 1.67 & 1.58 & 3.11 & 6.36 \\
\hline Scombridae & 3.42 & 2.79 & 1.61 & 7.82 \\
\hline Soleidae & 1.28 & 1.81 & 0.56 & 3.65 \\
\hline Sphyraenidae & 1.93 & 0.00 & 0.00 & 1.93 \\
\hline
\end{tabular}

Table 4. Jaccard's dissimilarity index of fish eggs within three neritic zones (inner, middle and outer) in the Sarawak EEZ of the South China Sea.

\begin{tabular}{ll}
\hline Neritic zone & Jaccard's dissimilarity index $(\%)$ \\
\hline Innervs Middle & 25 \\
Innervs Outer & 25 \\
Middle vs Outer & 0 \\
\hline
\end{tabular}

Table 5. Range values of in-situ physicochemical water parameters in the three neritic zones according to depth profile in the Sarawak EEZ of the South China Sea.

\begin{tabular}{|c|c|c|c|c|c|c|c|}
\hline $\begin{array}{l}\text { Neritic } \\
\text { zone }\end{array}$ & Station no. & $\begin{array}{l}\text { Depth } \\
(\mathrm{m})\end{array}$ & $\begin{array}{l}\text { Temperature } \\
\left({ }^{\circ} \mathrm{C}\right)\end{array}$ & $\begin{array}{l}\text { Salinity } \\
\text { (PSU) }\end{array}$ & $\begin{array}{l}\mathrm{DO} \\
\left(\mathrm{mg} \cdot \mathrm{L}^{-1}\right)\end{array}$ & $\begin{array}{l}\text { Turbidity } \\
\text { (NTU) }\end{array}$ & $\mathrm{pH}$ \\
\hline \multirow[t]{4}{*}{ Inner } & 48 & 34 & $27.70-28.31$ & $33.60-34.10$ & $4.83-6.17$ & $0.01-0.30$ & $7.74-7.79$ \\
\hline & 2 & 37 & $27.75-29.60$ & $34.03-34.80$ & $5.30-6.10$ & 0.01 & $7.68-7.73$ \\
\hline & 6 & 50 & 29.20-30.13 & $34.10-34.80$ & $5.74-6.00$ & $0.01-0.07$ & $7.50-7.76$ \\
\hline & \multicolumn{2}{|c|}{ Max-min value } & 2.43 & 1.20 & 1.34 & 0.29 & 0.29 \\
\hline \multirow[t]{6}{*}{ Middle } & 108 & 59 & $26.00-27.07$ & $34.40-34.85$ & $5.90-6.53$ & $0.03-0.94$ & $7.76-7.79$ \\
\hline & 74 & 63 & $28.20-28.80$ & $34.00-34.50$ & $4.40-5.63$ & $0.03-0.43$ & $7.68-7.74$ \\
\hline & 77 & 69 & 27.35-28.90 & $34.13-34.73$ & $5.05-7.00$ & $0.01-0.57$ & $7.48-7.72$ \\
\hline & 27 & 77 & $25.40-28.00$ & $34.30-35.00$ & $5.70-7.17$ & 0.01 & $7.68-7.75$ \\
\hline & 76 & 92 & 21.68-28.20 & $34.13-35.13$ & $6.00-7.00$ & $0.02-0.47$ & 7.47-7.78 \\
\hline & \multicolumn{2}{|c|}{ Max-min value } & 7.22 & 1.13 & 2.77 & 0.93 & 0.32 \\
\hline \multirow[t]{8}{*}{ Outer } & 116 & 104 & $21.70-28.80$ & $34.20-35.35$ & $5.60-7.10$ & 0.01 & $7.53-7.75$ \\
\hline & 133 & 105 & $20.70-28.70$ & $33.10-35.23$ & $4.73-7.53$ & $0.06-0.83$ & $7.48-7.75$ \\
\hline & 139 & 113 & $21.20-28.01$ & $33.00-35.30$ & $4.93-7.50$ & $0.13-0.96$ & $7.55-7.75$ \\
\hline & 118 & 121 & $21.00-29.13$ & $34.20-35.33$ & $4.70-7.50$ & 0.01 & $7.47-7.73$ \\
\hline & 130 & 135 & $19.60-28.70$ & $34.30-35.30$ & $4.70-7.50$ & $0.01-0.24$ & $7.56-7.70$ \\
\hline & 136 & 150 & $18.80-27.23$ & $34.47-35.23$ & $4.70-6.00$ & $0.07-0.75$ & $7.43-7.76$ \\
\hline & 117 & 153 & 20.30-27.90 & $33.00-35.40$ & $6.20-7.53$ & 0.01 & $7.53-7.78$ \\
\hline & \multicolumn{2}{|c|}{ Max-min value } & 10.33 & 2.40 & 2.83 & 0.95 & 0.35 \\
\hline
\end{tabular}

range values were lower $\left(4.40 \mathrm{mg} \cdot \mathrm{L}^{-1}\right.$ to $\left.6.00 \mathrm{mg} . \mathrm{L}^{-1}\right)$ than the inner neritic zone. The minimum value for turbidity was similar to the inner neritic zone but the maximum value was higher (0.01 NTU to 0.94 NTU).
The minimum value of $\mathrm{pH}$ was lower than the inner neritic zone but the maximum value remained the same (7.47 to 7.79 ). 
At outer neritic zone, minimum temperature value was the lowest among the three zones $\left(18.80{ }^{\circ} \mathrm{C}\right.$ to $29.13^{\circ} \mathrm{C}$ ). The salinity ranged from 33.00 PSU to 35.40 PSU and this zone recorded the lowest minimum and the highest maximum salinity value among the three zones. The DO ranged from $4.70 \mathrm{mg} . \mathrm{L}^{-1}$ to $7.53 \mathrm{mg} . \mathrm{L}^{-1}$ and this zone recorded the highest maximum value among the three zones. The range value of turbidity was almost similar to other zones (0.01 NTU to 0.96 NTU). The minimum $\mathrm{pH}$ value was the lowest among the three zones (7.43 to 7.78). The outer neritic zone showed a wider range, followed by middle and the inner neritic zones when comparing the differences between maximum and minimum values of each parameter among the zones.
The depth profiles of temperature, salinity, pH, DO and turbidity were analysed according to three zones using Pearson correlation coefficient (Table 6). Temperature showed significant negative correlations with depth in the inner (weak) and outer (very strong) neritic zones while the salinity showed significant positive correlations with depth in inner (moderate) and outer (strong) neritic zones. For pH, it showed significant negative correlations in the middle (moderate) and outer (weak) neritic zones. For DO, significant positive correlations with depth were observed only in the outer (moderate) neritic zone. In contrast, turbidity did not show any significant correlation for all zones.

Table 6. Pearson correlation coefficient between all physicochemical parameters of water (two-tailed) within three neritic zones Sarawak EEZ of the South China Sea.

\begin{tabular}{llllll}
\hline Neritic zone & $\begin{array}{l}\text { Temperature } \\
\left({ }^{\circ} \mathrm{C}\right)\end{array}$ & $\begin{array}{l}\text { Salinity } \\
(\mathrm{PSU})\end{array}$ & $\mathrm{pH}$ & $\begin{array}{l}\text { DO } \\
\left(\mathrm{mg} . \mathrm{L}^{-1}\right)\end{array}$ & $\begin{array}{l}\text { Turbidity } \\
\text { (NTU) }\end{array}$ \\
\hline Inner & $-0.393^{* *}$ & $0.515^{* *}$ & 0.208 & 0.002 & 0.073 \\
Middle & -0.186 & 0.193 & $-0.552^{* *}$ & 0.097 & -0.015 \\
Outer & $-0.912^{* *}$ & $0.656^{* *}$ & $-0.379^{* *}$ & $0.475^{* *}$ & 0.165 \\
\hline
\end{tabular}

**Significant at 0.01 level.

\section{Relationship between fish egg family abundance and distribution with environmental parameters according to zone}

\begin{abstract}
The relationship between fish egg assemblages with the environmental variables in the Sarawak EEZ of the South China Sea is shown in CCA ordination diagram (Fig. 6). The CCA results on environmental parameters and fish egg family are best explained by Axis 1 and 2 with a total variance of $70.39 \%$. The results of the permutation test of 999 showed that the test of axis 1 and axis 2 canonical eigenvalues were 0.122 and 0.076 , respectively and the $P$ value was less than 0.05 , indicating that both canonical axes were statistically significant at $P<0.05$. The position of the family on the CCA biplot is a reflection of the environmental conditions where it was found (Table 7).
\end{abstract}

The longest CCA vector was zone, followed by temperature, salinity, DO, turbidity and $\mathrm{pH}$ (Fig. 6). It was observed that Malacostidae and Muraenidae were associated with the outer neritic zone, high salinity, $\mathrm{DO}$ and turbidity but low with temperature and $\mathrm{pH}$. Besides, Labridae, Scombridae and Sphyraenidae were associated with the inner neritic zone that had higher temperature and $\mathrm{pH}$ but less influenced by salinity, DO and turbidity. Seven families did not show any relationship with environmental factors. Two families namely Clupeidae and Kyphosidae were distributed in all the neritic zones (inner, middle and outer), while the other five families namely Callionymidae, Carangidae, Cynoglossidae, Mugilidae and Soleidae were distributed only in middle neritic zone.

\section{Discussion}

\section{Composition, abundance and distribution of fish eggs}

The composition and assemblages of the fish eggs are closely linked to various aspects such as fish type (pelagic and demersal), spawning sites, spawning behaviour, water current, depth, underwater topography and water parameters (Mandic et al., 2014). In this study, the number of orders and families of fish eggs collected from the Sarawak EEZ were lower than the Vietnamese waters of the South China Sea which recorded nine orders and 14 families (Nguyen, 2001). Their study revealed three families, namely Clupeidae, Cynoglossidae and Soleidae that were also observed in the current study. The low similarity in composition between these studies may be due to different sampling months involved, in which Nguyen (2001) samples were obtained from April to May 1999, while the present study was done from August to October 2015. Sampling period has been reported to support fish assemblages of different composition, abundance and distribution (Curley et al., 2002; Chittaro, 2004). Besides, the depth of sampling area and the number of stations can also lead to different results, in which Nguyen (2001) samples were collected from $20 \mathrm{~m}$ to $4000 \mathrm{~m}$ depth at 58 stations while the samples in the present study were obtained from $20 \mathrm{~m}$ to $200 \mathrm{~m}$ depth at 38 stations. The different month of the sampling period, 
Table 7. Canonical component analysis $(P=0.05)$ for fish egg abundance with environmental parameters in the Sarawak EEZ of the South China Sea.

\begin{tabular}{lllll} 
& Axis & Eigen value & \% of variance & Pvalue \\
\hline Fish egg abundance and & 1 & 0.122 & 43.41 & 0.003 \\
environmental parameters & 2 & 0.076 & 26.98 & 0.001 \\
\hline
\end{tabular}

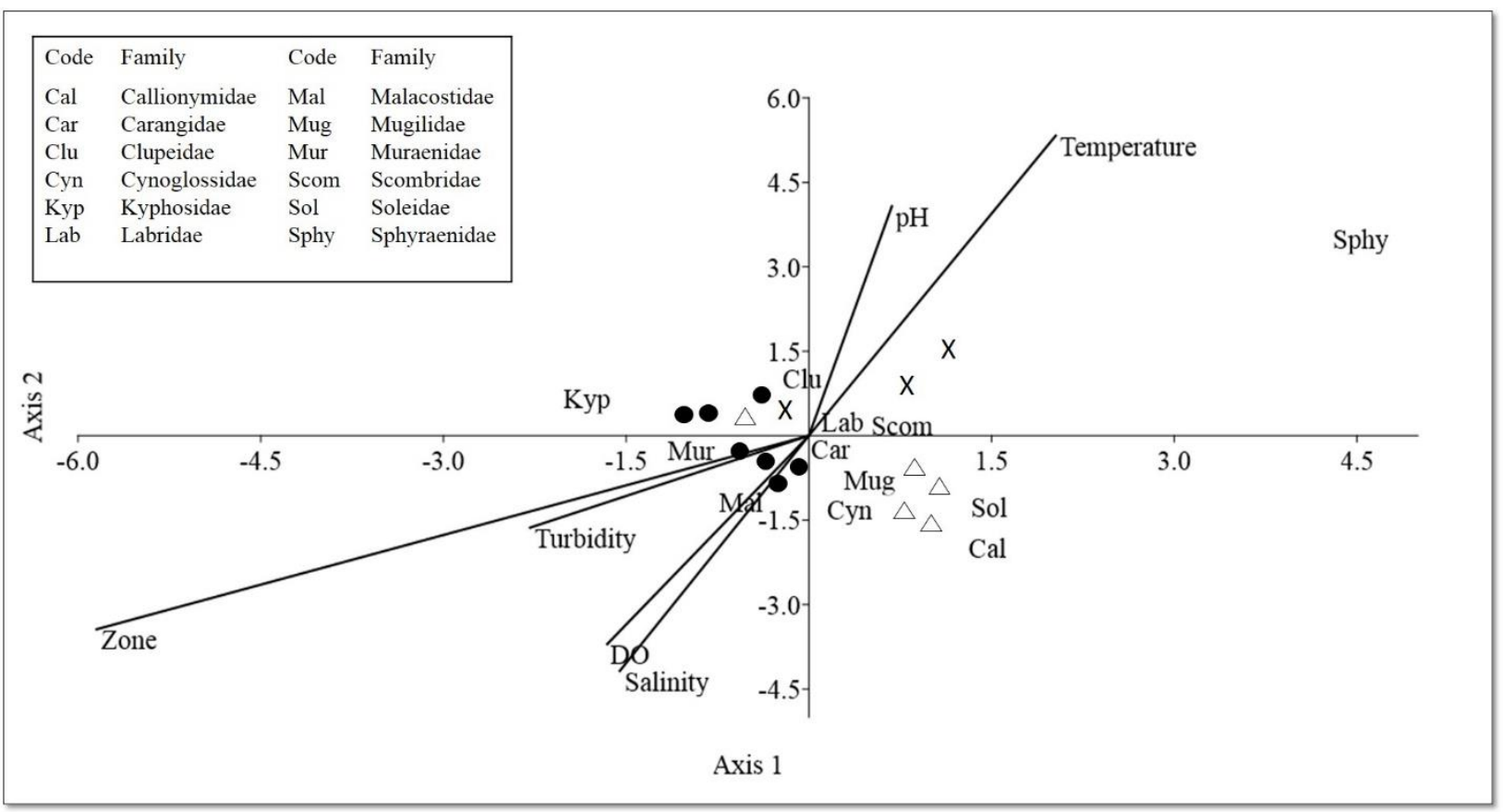

Fig. 6. Biplot diagram of canonical correspondence analyses showing the relationship between the abundance of fish eggs in the Sarawak EEZ of the South China Sea with six environmental variables at three neritic zones; inner, middle and outer. Symbols: $X$ (inner), triangle (middle) and dot (outer); arrow represent the physicochemical water parameters such as temperature, $\mathrm{pH}$, salinity, turbidity and $\mathrm{DO}$. The fish egg codes are listed by the first letter of the family.

depth of sampling area and sampling strategy for both studies lead to different findings as the abundance of fish eggs is linked to the reproductive strategies of adult populations and their life cycles (HernandezMiranda et al., 2003).

Different monsoon also leads to a low similarity in composition of fish eggs between both studies. In Malaysia, there are two monsoons and two intermonsoon seasons. The Northeast monsoon is between December and February and followed by intermonsoon between March and May, while the Southwest monsoon is between June and August and followed by another intermonsoon between September and November (Ara et al., 2011a). In contrast, Vietnam has only two monsoon seasons each lasting 6 months, the Southwest monsoon is from April to September and the Northeast monsoon is from October to late March or early April (Travelfish, 2018). Thus, the sampling period of the current study was influenced by the Southwest monsoon and intermonsoon, while Nguyen (2001) sampled during Southwest monsoon in Vietnamese waters. Moreover, the different result for the composition of fish egg in
Nguyen (2001) study and this study may be due to the different direction of sea current. According to Akhir et al. (2014), the sea current is directed northward during the Southwest monsoon, while the Northeast monsoon reverses the direction of sea current. Besides, during the Southwest monsoon season, the sea current profile shows that it leans towards the coast of the South China Sea (Akhir, 2012).

The abundance of fish eggs can also be related to the zones and their habitats. In this study, the most abundant fish eggs were collected at the inner neritic zone, which is relatively shallower than middle and outer neritic zones. Shallow areas may support more suitable habitats for fish survival like seagrass beds and coral reefs due to better light penetration and these habitats usually provide adequate shelter and food resources for adults compared to deeper waters (Mateo et al., 2006).

The three most dominant fish eggs in the Sarawak EEZ water were from families Carangidae, Clupeidae and Scombridae and were found from all zones. The high density of selected fish egg of the three families 
in the water column is known to be associated with their spawning season. Carangidae is reported to be widely distributed in the tropical Indo-Pacific region and their spawning season usually occurs in September to October (Clarke, 1996) which coincides with the sampling period of this study in the Sarawak EEZ. This perhaps explains the reason for the abundance of Carangid eggs in the present study. Whereas the Clupeidae can spawn all year round (Macedo-Soares et al., 2009) and their fish larvae are reported to be dominant in Malaysian waters (Ara et al., 2011b). Moreover, the spawning season of Scombridae occurs from September to April (Wheeler, 1985), which coincides with the sampling period done for this study. Another reason why these three families are dominant in this study is probably they consist of many genera and species and lead to the high abundance of eggs.

In contrast, fish from the two families, namely Kyphosidae and Malacostidae are only found in middle and the outer neritic zones. Even though Kyphosidae is usually found in shallow water, their adults sometimes swim in schools at the outer neritic zone (Miller and Kendall, 2012). The adults of Malacostidae have been reported to inhabit the outer neritic zone (Miller and Kendall, 2012). This indicates that the nature of adult fish from Kyphosidae and Malacostidae might be the factor contributing to their eggs distribution as they spawn at their favourable habitats. In contrast, Sphyraenidae eggs were collected only at the inner neritic zone and in low density. The low density and distribution of Sphyraenid eggs were probably due to their unpredictable spawning period and patterns that differ according to different areas of the world (Blaber et al., 1997).

\section{Jaccard's dissimilarity index of fish egg assemblages}

Based on the Jaccard's dissimilarity index, the middle and outer neritic zones support the same fish eggs family assemblage, while comparison among other zones showed very low dissimilarities. This could be related to the influence of habitat homogeneity between middle and outer neritic zones, while the habitats at the inner neritic zone may differ with the deeper water zones. Furthermore, the physicochemical parameters of water at the inner neritic zone displayed narrower range values compared to middle and outer neritic zones. Ricklefs and Schluter (1993) suggest that both biotic and abiotic in the aquatic ecosystem may affect the composition and structure of fish egg community.

\section{Influence of physicochemical parameters of water to fish egg abundance and distribution}

Environmental parameters changed over time due to both anthropogenic and natural factors. The canonical correspondence analyses results showed that Malacostidae and Muraenidae were abundant in the habitat that is positively associated with an increase in salinity, DO and turbidity at the outer neritic zone. This is probably because the outer neritic zone receives oxygen through mixing by wind, currents and inflows (Poxton and Allouse, 1982). Moreover, the effect of salinity on the development of marine fish eggs was reflected by the availability of oxygen (Regner, 1996). Thus, spawning of Malacostidae and Muraenidae fishes seems to require favourable environmental conditions for eggs (Norcross and Shaw, 1984). Furthermore, Malacostidae and Muraenidae preferred habitat with higher turbidity, which probably was because of the reproductive strategies of adult fish to spawn (Hernandez-Miranda et al., 2003).

For Labridae, Scombridae and Sphyraenidae, they can be found in a habitat that is positively associated with an increase in temperature and $\mathrm{pH}$ at the inner neritic zone. Laprise and Pepin (1995) reported that temperature is important to fish egg and some fish require warm water for spawning (Nguyen, 2001). Although the Labridae, Scombridae and Sphyraenidae eggs seem to require higher $\mathrm{pH}$, however lower $\mathrm{pH}$ values (7.50 to 7.79) were recorded at the inner neritic zone in this study compared to normal $\mathrm{pH}$ for the ocean (8.2). Thus, these families might be vulnerable to the ocean acidification problem.

\section{Conclusion}

This is the first attempt to investigate the fish egg composition, abundance and distribution in three zones with physicochemical parameters of waters in the Sarawak EEZ of the South China Sea. In total, 3,935 fish eggs belonging to six orders from 12 families were found in the study area. The highest fish egg density was recorded at the inner neritic zone while the assemblage of fish egg family was similar at middle versus the outer neritic zones. Based on CCA, the abundance of Labridae, Malacostidae, Muraenidae, Scombridae and Sphyraenidae were influenced by all environmental parameters (zone, temperature, salinity, DO, turbidity and $\mathrm{pH}$ ). Ichthyoplankton assemblages are very dynamic and can be influenced by many factors that change with monsoon seasons. Thus, a periodical survey needs to be conducted to establish a fishery-independent stock assessment for the management of fisheries at the Sarawak EEZ of the South China Sea.

\section{Acknowledgements}

We wish to express our gratitude to Universiti Malaysia Sarawak and Department of Fisheries, Malaysia for providing facilities and logistic support during this study. Special thanks to M V SEAFDEC 2 research vessel crews, UNIMAS staffs, friends and those who had involved directly during the cruise expedition. 


\section{References}

Ahlstrom, E.H., Moser, H.G. 1976. Eggs and larvae of fishes and their role in systematic investigations in fisheries. Revue des Travaux de I'Institut des Peches Maritimes 40:379-398.

Akhir, M.F.M. 2012. Surface circulation and temperature distribution of Southern South China Sea from Global Ocean Model (OCCAM). Sains Malaysiana 41:701-714.

Akhir, M.F.M., Zakaria, N. Z., Tangang, F. 2014. Intermonsoon variation of physical characteristics and current circulation along East Coast of Peninsular Malaysia. International Journal of Oceanography 2014:1-9. https://doi.org/10.1155/2014/527587

Ara, R., Arshad, A., Amin, S.M.N., Daud, S.K., Mazlan, A.G. 2011a Comparison of larval fish density between seagrass beds of the Southwestern Johor, Peninsular Malaysia. Journal of Fisheries and Aquatic Science 6:795-801. https://doi.org/10.3923/jfas.2011.795.801 Ara, R., Aziz, A., Nurul, S.M.A., Siti, K.D., Mazlan, A.G. 2011b. Environment and diversity of ichthyoplankton in the seagrass beds of Sungai Pulai estuary, Johor, Peninsular Malaysia. Journal of Food Agriculture and Environment 9:733-738.

Blaber, S.J., Farmer, M.J., Milton, D.A., Pang, J., Boon-Teck, O., Wong, P. 1997. The ichthyoplankton of selected estuarine in Sarawak and Sabah: Composition, distribution and habitat affinities. Estuarine Coast Shelf Science 45:197-208. https://doi.org/10.1006 lecss.1996.0174

Chittaro, P.M. 2004. Fish-habitat associations across multiple spatial scales. Coral Reefs 23:235-244. http://doi.org/10.1007/s00338-004$\underline{0376-z}$

Clarke, T.A. 1996. Reproductive biology and egg abundance of the yellowtail scad or omaka, Atule mate (Carangidae), in Kaneohe Bay, Hawaii. Pacific Science 50:93-107.

Curley, B.G., Kingsford, M.J., Gillanders, B.M. 2002. Spatial and habitatrelated patterns of temperate reef fish assemblages: Implications for the design of marine protected areas. Marine Freshwater Research 53:1197-1210. http://doi.org/10.1071/MF01199

Fish Database of Taiwan 2014. An identification guide of marine fish eggs from Taiwan. https://fishdb.sinica.edu.tw/chi/fishegg /fisheggintro_e.php (Accessed 13 October 2017).

Hernandez-Miranda, E., Palma, A.T., Ojeda, F.P. 2003. Larval fish assemblages in nearshore coastal waters off central Chile: Temporal and spatial patterns. Estuarine, Coastal and Shelf Science 56:10751092. https://doi.org/10.1016/S0272-7714(02)00308-6

Jeyaseelan, M.J.P. 1998. Manual of fish eggs and larvae from Asian mangrove water. UNESCO Publishing, France. 193 pp.

Kelso, W.E., Rutherford, D.A. 1996. Collection, preservation, and identification of fish eggs and larvae. In Fisheries techniques, Murphy, B.R., Willis, D.W. (Eds.), American Fisheries Society, Bethesda, Maryland, USA, pp. 255-302.

Laprise, R., Pepin, P. 1995. Factors influencing the spatio-temporal occurrence of fish eggs and larvae in a northern, physically dynamic coastal environment. Marine Ecology Progress Series 122:3-92. http://doi.org/10.3354/meps122073

Macedo-Soares, L.C.P., Birolo, A.B., Freire, A.S. 2009. Spatial and temporal distribution of fish eggs and larvae in a subtropical coastal lagoon, Santa Catarina State, Brazil. Neotropical Ichthyology 7:231240. http://dx.doi.org/10.1590/S1679-66252009200015

Mandic, M., Regner, S., Gacic, Z., Durovic, M., Markovic, O., Ikica, Z. 2014. Composition and diversity of ichthyoplankton in the Boka Kotorska Bay (South Adriatic Sea). Acta Adriatica 55:229-244.

Mateo, M.A., Cebrián, J., Dunton, K., Mutchler, T. 2006. Carbon flux in seagrass ecosystems. In: Seagrasses: Biology, ecology and conservation, Larkum, A.W.D., Orth, R.J., Duarte, C. (Eds.), Springer, Netherlands, pp. 159-192.

Miller, B.S., Kendall, A.W. 2012. Fish reproduction. In: Early life history of marine fishes, Nummela, S. (Ed.), University of California Press, California. $376 \mathrm{pp}$.

Muhamad, N. 2017. Ichthyoplankton assemblages and its distribution along selected Sarawak coastal waters. Master's Thesis. UNIMAS Kota Samarahan, Sarawak, Malaysia.

Muhamad, N., Rahim, S.A.K.A. 2014. Preliminary study on fish larvae at selected coastal waters of Sarawak. Borneo Journal of Resource Science and Technology 4:1-8. https://doi.org/10.33736 /bjirst.231.2014

Nguyen, D.V. 2001. Composition, abundance and distribution of fish eggs and larvae in the South China Sea, Area IV: Vietnamese waters. In proceedings of the fourth technical seminar on marine fishery resources survey in the South China Sea, Area IV: Vietnamese waters, 18-20 September 2000, pp. 94-145. Southeast Asian Fisheries Development Center, Bangkok, Thailand.

Norcross, B.L., Shaw, R.F. 1984. Oceanic and estuarine transport of fish eggs and larvae: A review. Transaction of American Fisheries Society 113:153-165. $\quad$ https://doi.org/10.1577/15488659(1984)113<153:OAETOF>2.0.CO:2

Okiyama, M. 2014. An atlas of early life stages in Japan. $2^{\text {nd }}$ Edition. Tokai University Press, Tokyo, Japan. 1896 pp.

Posgay, J.A., Marak, R.R. 1980. The MARMAP bongo zooplankton samplers. Journal of Northwest Atlantic Fishery Science 1:91-99. http://doi.org/10.2960/J.v1.a9

Poxton, M.G., Allouse, S.B. 1982. Water quality criteria for marine fisheries. Aquaculture Engineering 1:153-191. https://doi.org /10.1016/0144-8609(82)90026-7

Ré, P., Meneses, I. 2008. Early stages of marine fishes occurring in the Iberian Peninsula. IPIMAR/IMAR, Lisbon. $282 \mathrm{pp}$.

Regner, S. 1996. Effects of environmental changes on early stages and reproduction of anchovy in the Adriatic Sea. Science Marine 60:167177.

Rester, J.K., Sanders, N., Hanisko, D.S., Pellegrin. B. 1998. SEAMAP environmental and biological atlas of the Gulf of Mexico. Gulf States Marine Fisheries Commission, Ocean Springs. 70 pp.

Ricklefs, R.E., Schluter, D. 1993. Species diversity in ecological communities. Historical and geographical perspectives. The University of Chicago Press, Chicago, USA. 414 pp.

Sanches, P.V., Nakatani, K., Bialetzki, A. 1999. Morphologica description of the developmental stages of Parauchenipterus galeatus (Linnaeus, 1766) (Siliriformes, Auchenipteridae) on the floodplain of the upper Paraná River. Revista Brasileira de Biologia 59:429-438.

Ter Braak, C.J.F. 1986. Canonical correspondence analysis: a new eigenvector technique for multivariate direct gradient analysis. Ecology 67:1167-1179. http://dx.doi.org/10.2307/1938672

Ter Braak, C.J.F. 1994. Canonical community ordination. Part I: Basic theory and linear methods. Ecoscience 1:127-140. https://doi.org /10.1080/11956860.1994.11682237

Travelfish. 2018. Weather in Vietnam. https://www.travelfish.Org/ weather/vietnam. (Accessed 22 January 2020).

Wheeler, A. 1985. The encyclopaedia of fishes. Macdonald, London. 368 pp.

Whittaker, R.H. 1960. Vegetation of the Siskiyou Mountains, Oregon and California. Ecological Monographs 30:279-338. http://doi.org $\underline{110.2307 / 1943563}$ 